\title{
ע Kuvaileva kirjallisuuskatsaus vanhempien lapsiinsa kohdistaman väkivallan loppumiseksi tarkoitetun CPC-CBT -työmenetelmän kansainvälisistä tutkimuksista
}

Väkivaltatyön palvelut ovat tavanomaisesti erillistä työskentelyä lapsille ja vanhemmille. Vanhempien lapsiinsa kohdistamassa kuritusväkivallassa on usein kyse vuorovaikutuksen, vanhemmuuden taitojen ja ylisukupolvisten pulmien vaikutuksesta vanhemmuuteen. Silti palveluvalikostamme puuttuu näyttöön perustuvia väkivaltatyön työmuotoja, joissa vanhemmat ja lapset olisivat yhtäaikaisessa työskentelyssä.

Tämä artikkeli käsittelee Yhdysvalloissa kehitettyä, näyttöön perustuvaa Combined Parent-Child Cognitive Behavioral Therapy -menetelmää (CPC-CBT), jonka tavoitteena on saada vanhempien lapsiinsa kohdistama kuritusväkivalta loppumaan ja parantaa vanhempien ja lasten keskinäistä vuorovaikutusta. Menetelmä soveltuu myös ennaltaehkäisevästi kaltoinkohtelun riskin vähentämiseen. Mallissa työskennellään samanaikaisesti sekä lasten että vanhempien kanssa, erikseen ja yhdessä.

Artikkeli on kuvaileva kirjallisuuskatsaus, joka tarjoaa tutkimustietoa CPC-CBT -työmuodosta. Aineistoon valittiin 17 tutkimusta tai raporttia kesällä 2018. Tutkimusmenetelmä on sisällönanalyysi. Tuloksissa on esitetty lasten, vanhempien ja työntekijöiden kokemuksia CPC-CBT -työskentelyyn osallistumisesta ja työskentelyllä tavoiteltuihin muutoksiin pääsemisestä. Lisäksi artikkelissa on tarkasteltu aiemmissa kirjallisuuskatsauksissa raportoituja, menetelmällä saavutettuja muutoksia perheissä sekä tutkimuksista saatua tietoa menetelmää käyttävien työntekijöiden tietotaitovaatimuksista.

Työskentelystä on saatu hyviä kokemuksia sekä työmuodon kehittäjämaassa Yhdysvalloissa että Ruotsissa. Tutkimusten tulosten mukaan kuritusväkivalta on loppunut tai vähentynyt, lasten posttraumaattiset oireet ovat vähentyneet, lasten ja vanhempien vuorovaikutus on parantunut ja positiivinen kasvatus on lisääntynyt. Lisätutkimusta tarvitaan vielä, sillä tutkimukset ovat osin pilottitutkimuksia pienillä otoksilla vailla pitkän ajan seurantaa.

ASIASANAT: Combined Parent-Child Cognitive Behavioral Therapy, kaltoinkohtelu, kuritus, menetelmä

MERJA KORTELAINEN, RIITTA VORNANEN, MERJA ANIS 


\section{YDINASIAT}

- $\quad$ CPC-CBT on näyttöön perustuva väkivaltatyön työmuoto koko perheelle.

- CPC-CBT -työskentelyn tuloksena vanhempien lapsiinsa kohdistama kuritusväkivalta on loppunut tai vähentynyt ja perheenjäsenten hyvinvointi on lisääntynyt.

- CPC-CBT -menetelmän käyttöönotosta on saatu hyviä kokemuksia kehittäjämaan ulkopuolella.

- Kokemusten kerääminen ja vaikuttavuuden tutkiminen ovat tärkeitä tulevaisuudessa.

\section{JOHDANTO}

Vanhempien lapsiinsa kohdistama väkivalta on merkittävä lasten hyvinvointia vahingoittava tekijä. Kouluterveyskyselyn 2019 mukaan $13 \%$ vastanneista alakoululaisista ja $12 \%$ yläkoululaisista oli kokenut fyysistä väkivaltaa viimeisen vuoden aikana vanhemman roolissa olevan taholta (1). Pieniin lapsiin kohdistuneista rikosepäilyistä jopa $90 \%$ on perheensisäistä fyysistä väkivaltaa (2). Tietoisuus väkivallan kauaskantoisista vaikutuksista vaikuttaa olevan yleistä (3). Silti tukistamista ja luunapin antamista ei vanhempien asenteissa aina mielletä väkivallaksi. Tietyissä tilanteissa niiden käytön hyväksyy melkein kolmannes vanhemmista. (4.) Äitien ja isien omaan raportointiin perustuvien tutkimusten mukaan $6 \%$ vastaajista ilmoitti käyttäneensä vakavaa väkivaltaa (lyöminen, pureminen, potkaiseminen, ravistelu) lastaan kohtaan viimeisen vuoden aikana $(5,6)$. Lievimpien väkivallan muotojen käyttö kasvatuksessa nosti vanhemman riskiä käyttää vakavaa väkivaltaa 11 kertaa suuremmaksi verrattuna vanhempiin, jotka pidättäytyivät fyysisen väkivallan käytöstä kasvatuksessa (6).

Väkivallalla tarkoitetaan vallan, kontrollin tai fyysisen voiman tahallista käyttöä tai sillä uhkaamista siten, että tämä kohdistuu toiseen ihmiseen tai ihmisryhmään ja että tämä johtaa tai voi johtaa fyysisen tai psyykkisen vamman syntymiseen, kehityksen häiriytymiseen, perustarpeiden tyydyttymättä jäämiseen tai kuolemaan. Lapseen kohdistuva fyysinen väkivalta (child physical abuse) on yksi väkivallan ilmenemismuoto, mikä ilmenee lapsen ruumiillisen koskemattomuuden tahallisena loukkauksena. (7.) Kuritusväkivalta (corporal punishment) tarkoittaa toimintaa, jossa lasta pyritään rankaisemaan ja säätelemään hänen käytöstään aiheuttamalla tahallisesti ruu- miillista tai henkistä kipua tai kärsimystä (4). THL:n väkivaltakäsitteiden sanastossa sitä ei ole haluttu määritellä omaksi kokonaisuudeksi, ettei tule mielikuvaa siitä, että minkäänlainen väkivalta olisi hyväksyttävää lasten kasvattamista (7). Tässä artikkelissa kuritusväkivalta -käsite on käytössä, sillä se on tutkimusaineistoissa käytetty termi.

Vanhempien lapsiinsa kohdistamassa kuritusväkivallassa on usein kyse vuorovaikutuksen pulmista, vanhemmuuden taitojen puutteista ja omassa lapsuudessa koetun väkivallan vaikutuksista vanhemmuuteen $(5,6)$. Väkivallasta kysyttäessä erityisesti äidit ovat halukkaita kertomaan lapsiinsa kohdistamasta kuritusväkivallasta. Heidän mukaansa tarpeisiin vastaavia palveluja vanhemmuuteen on hankala Suomessa löytää. (6.)

Kansalliset säädökset (8) ja kansainväliset sopimukset $(9,10)$ velvoittavat lasten kohtaaman väkivallan vastaiseen työhön. Tutkimusnäyttöön perustuvien, strukturoitujen vanhemmuusohjelmien käyttöönoton tärkeys lapsiin kohdistuvassa väkivaltatyössä on nostettu esiin myös Väkivallaton lapsuus -toimenpideohjelmassa 2020-2025 (11). Erilaisiin tarpeisiin suunnattujen tukipalvelujen saatavuus ja huolellinen arvio työskentelyn sopivuudesta sitä tarvitseville on tärkeää, ettei tulisi turhautumisia ja aloitettujen palvelujen keskeytyksiä (12). Näyttöön perustuvien työmuotojen lisääntyminen on avannut mahdollisuuden arvioida työmuotojen sopivuutta. Tieto tuloksista ja siitä, miten, kenelle ja miksi mikäkin menetelmä on käytettävissä, antaa pohjaa oikeaan osuvalle työmuodon valinnalle. (13.) Väkivallan ja trauman hoitoon lapsilla käytettävistä näyttöön pohjautuvista menetelmistä osa on suunnattu pelkästään lapsille $(14,15)$. Menetelmissä, joissa vanhempi on mukana, vanhemman kanssa käsiteltävät teemat vaihtelevat, työskentely on erillistä tai lapsen kanssa yhteistä ja vanhemman rooli tekijänä, väkivaltaa käyttämättömänä ja väkivallan käytön riskissä olevana määrittelee mukaan pääsyä (15). Suomesta puuttuu koko perheelle suunnattu näyttöön perustuva väkivaltatyön työmuoto.

Tässä tutkimuksessa tutkimme koko perheelle, vanhempien ja lasten yhtäaikaiseen työskentelyyn tarkoitettua Combined Parent-Child Cognitive Behavioral Therapy -menetelmää (myöhemmin CPC-CBT) (16). Ruotsissa CPC-CBT:tä on mallinnettu ja toteutettu vuodesta 2006 läh- 
tien. Menetelmän ruotsalainen nimi on KIBB, Kognitiv Integrerad Behandling vid Barnmisshandel. $(17,18$.) Suomessa Ensi- ja turvakotien liitto pilotoi CPC-CBT:tä osana Ylisukupolvisen kaltoinkohtelun katkaiseminen -hanketta. Mukana pilotointityössä ovat Viola -väkivallasta vapaaksi ry ja Vaasan ensi- ja turvakoti ry.

Lapseen kohdistuvan väkivallan loppumiseen tähtäävistä menetelmistä on tärkeää tutkia, miten niiden toimivuutta voi parantaa osoittamalla niiden mekanismeja vähentää tai ehkäistä lasten ruumiillista kuritusta $(13,15,19,20)$ ja miten ne on siirretty teoriasta käytäntöön (13). Ennen käyttöönottoa työntekijöiden on syytä etsiä tutkimustietoa tarjolla olevista työmuodoista käytännössä, jotta tulisi ilmi, mitä positiivisia ja realistisia tuloksia työmuodolla voi olla (21). Vertailevaa tutkimusta lasten kaltoinkohtelun ehkäisyyn ja hoitoon suunnatuista menetelmistä tulisi tehdä enemmän, ja tutkimustietoa tulisi olla kootusti työntekijöille saatavilla (19).

Tässä tutkimuksessa halusimme saada selville, miten CPC-CBT -työmuotoa on käytetty perheiden kanssa tehtävässä väkivaltatyössä ja millaisia kokemuksia lapsilla, vanhemmilla ja työntekijöillä on CPC-CBT:n käytöstä. Tieto on tärkeää menetelmän käytettävyyden arvioimiseksi Suomessa.

Tutkimuskysymyksenä on:

Millaisia tutkimustuloksia on kansainvälisesti saatu CPC-CBT -työmuodosta?

Tämä tutkimus on tehty kuvailevana kirjallisuuskatsauksena, koska on pyritty saamaan tutkimusaineistoon kaikki se tieto, mitä eri maista on saatavilla CPC-CBT -työmuodosta. Ennakko-oletuksena oli, että tehtyjen tutkimusten määrä on pieni.

\section{COMBINED PARENT-CHILD COGNITIVE BEHAVIORAL THERAPY}

CPC-CBT:n on Yhdysvalloissa kehittänyt Melissa Runyon työryhmineen (Cares Institute, Child Abuse Research Education and Service) (16). California Evidence-Based Clearinghouse for Child Welfare -rekisteri (CEBC) kokoaa tietoa lapsille ja perheille suunnatuista interventioista. CPC-CBT sisältyy rekisteriin ja on luokiteltu siinä lupaavana tutkimusnäyttöön perustuvana työmuotona ja lasten hyvinvointiin tähtäävien palvelujen käyttötarkoituksessa korkeimmalla luokituksella. (22.)
CPC-CBT on suunnattu perheille, joissa vanhempi on kohdistanut fyysistä väkivaltaa tai muuta kuritusväkivaltaa lastaan kohtaan tai vanhempi on riskissä käyttäytyä väkivaltaisesti lastaan kohtaan $(16,23,24)$. Työskentelyyn osallistuvat vanhemman roolissa olevat ja perheen 3-17-vuotiaat lapset. Menetelmä sisältää 16-20 kerran viikossa toteutettavaa tapaamista yhden perheen työskentelynä tai ryhmämuotoisena työskentelynä. Tapaamiskertojen aluksi vanhemmat ja lapset työskentelevät erikseen. Lopuksi perhe harjoittelee yhdessä teemana olleita taitoja. Tapaamisen kesto on 90 minuuttia ja ryhmämuotoisena kaksi tuntia kerrallaan. Strukturoidusta työskentelyrakenteesta huolimatta työskentely räätälöidään perheiden tarpeiden mukaiseksi. Arviointi menetelmän sopivuudesta perheelle tehdään huolella, ja turvallisuus on läpi koko työskentelyn huomioitava asia. Työskentelyn edellytys on, että vanhemmat sitoutuvat väkivallattomuuteen. Vanhemmat sitoutuvat myös avoimuuteen tuomalla työskentelyyn tietoa perheessä sattuneista tilanteista. $(16,23,25,26$.) Mahdollisesta työskentelyn aikana ilmenneestä väkivallasta ollaan yhteydessä lastensuojeluun (16).

Työskentelyssä on neljä osaa. Ensimmäiset tapaamiskerrat sisältävät motivoinnin ja työskentelyyn kiinnittymisen elementtejä sekä psykoedukatiivisen työskentelyn. Perheen tarpeista lähtevä taitojen lisääminen on toinen osa työskentelyä. Perheen turvasuunnitelman laadintaan siirrytään riittävien taitojen omaksumisen jälkeen. Viimeisenä on selventävä työskentelyvaihe, jossa lapset käsittelevät huolellisen ja asteittain tapahtuvan altistumisen kautta omia väkivaltakokemuksiaan ja vanhemmat ottavat vastuun käytöksestään. Työntekijät arvioivat perheenjäsenten valmiutta tähän työskentelyvaiheeseen ja etenevät perheenjäsenten valmiuksia huomioiden. $(16,23,26$.) Pääteemojen jakaantuminen tapaamiskerroille on esitetty taulukossa yksi. (Taulukko 1.)

Työskentely pohjautuu kognitiivis-behavioraaliseen teoriaan sisältäen elementtejä aiemmin kehitetyistä kognitiivis-behavioraaliseen teoriaan pohjautuvista menetelmistä seksuaalisen, fyysisen tai lähisuhdeväkivallan hoitoon. Myös motivoivat menetelmät, perhesysteeminen lähestymistapa sekä trauma- ja kehitysteoriat ovat työmenetelmän taustalla. (23,25-27.) Mallin kehittäjät uskovat olevan hyödyllistä, kun yksi inter- 
Taulukko 1. CPC-CBT -työskentelyn rakenne pääpiirteissään

\begin{tabular}{|l|l|}
\hline $\begin{array}{l}\text { Tapaamiskertojen (1-16) } \\
\text { jakaantuminen neljään } \\
\text { osa-alueeseen }\end{array}$ & Keskeisimmät teemat \\
\hline $\begin{array}{l}\text { Kiinnittyminen ja } \\
\text { psykoedukaatio (1-3) }\end{array}$ & $\begin{array}{l}\text { Tutustuminen, motivoituminen ja sitoutuminen työskentelyyn, tavoitteet } \\
\text { työskentelylle, tieto ilmiöstä ja vanhemmille myös lasten kehityksestä. } \\
\text { Lapset aloittavat myös tunteiden käsittelyn. }\end{array}$ \\
\hline Taidot (4-7) & $\begin{array}{l}\text { Perheen tarpeiden mukaiset selviytymis-, tunne- ja vanhemmuustaidot, } \\
\text { vihan hallinta, itsestä huolehtiminen. Opitun harjoittelua. }\end{array}$ \\
\hline Turvallisuus (8-11) & $\begin{array}{l}\text { Perheen turvasuunnitelman laadinta ja harjoitukset. Vanhempien ja lasten } \\
\text { tarpeista esiin tulleiden taitojen harjoittelua. }\end{array}$ \\
\hline $\begin{array}{l}\text { Väkivaltakokemuksen } \\
\text { selventäminen ja } \\
\text { vastuunotto (12-16) }\end{array}$ & $\begin{array}{l}\text { Lapset kokoavat traumanarratiivin kaltoinkohtelun kokemuksistaan työnte- } \\
\text { kijän tuella kirjoittaen kirjeen vanhemmilleen tai tekemällä muun tuotoksen. } \\
\text { Vanhemmat vastaavat lasten kirjeeseen ja ottavat vastuun käytöksestään. }\end{array}$ \\
\hline
\end{tabular}

ventio pystyy auttamaan lapsia selviämään traumasta ja väkivallasta, sekä voimaannuttaa ja motivoi vanhempia säätelemään tunteitaan ja käyttämään väkivallattomia vanhemmuuden keinoja. Työskentely parantaa vanhemman ja lapsen välistä vuorovaikutusta sekä vahvistaa heidän suhdettaan auttamalla vanhempia lopettamaan väkivallan kierre (26).

Kognitiivis-behavioraalista lähestymistapaa pidetään tehokkaana menetelmänä vähentämään vanhemman aggressiota ja väkivallan käytön todennäköisyyttä kasvatuksessa (28). CPC-CBT -työskentelyssä työntekijä auttaa vanhempaa luomaan ja vahvistamaan toimivia taitoja ja selviytymisstrategioita käytännön perhe-elämään. Perheessä tapahtuneiden tilanteiden tarkka läpikäyminen sekä niihin liittyvien ajatusten, tunteiden ja toiminnan tarkastelu ovat keskeisiä uusien käyttäytymismallien omaksumisessa. (25.) Tuloksellinen työskentely edellyttää työntekijältä sekä menetelmäosaamista että soveltuvuutta uudenlaiseen työskentelytapaan (29). Positiivisten kasvatuskeinojen lisääntyminen arjessa auttaa vanhempaa huomaamaan niiden toimivuuden. Vuorovaikutussuhteen paraneminen vanhemman ja lapsen välillä puolestaan muuttaa kodin ilmapiiriä. (16.)

\section{TUTKIMUSMENETELMÄ JA AINEISTO}

Kirjallisuuskatsauksella kartoitetaan tietoa siitä, mitä kyseisestä tutkittavasta aiheesta jo tiedetään aiemman tutkimuksen valossa (30). Koottu, tiivistetty tieto helpottaa käytännön työntekijöitä työskentelymenetelmän valinnassa (31). Yksi kirjallisuuskatsauksen muoto on kuvaileva kirjallisuuskatsaus, mikä pitää sisällään aikaisemman tiedon kokoamista, kuvaamista ja tarkastelua yleiskatsauksena ilman tarkkoja ja tiukkoja sääntöjä. Erityispiirteinä sillä on aineistolähtöisyys ja ymmärtäminen. (32.) Artikkelimme on aineistolähtöinen, kuvaileva kirjallisuuskatsaus CPC-CBT -työmuodosta.

Aineiston etsinnässä käytettyjä tietokantoja olivat Google Scholar, Academic Search Premier, SocINDEX with Fulltext, Social Science Database, Sociology Database, Scopus ja lisäksi vielä artikkelihaku Turun yliopiston kirjaston Volterista. Valintakriteerinä olivat systemaattisella tiedonhaulla ja tiedonhaulla saadun aineiston viitteitä läpikäymällä saadut tutkimukset, raportit, artikkelit, työmuodon ohjeistukset ja käsikirjat, jotka käsittelevät CPC-CBT -työmuotoa ja ovat saatavilla kokotekstinä englannin- tai ruotsinkielisenä ilman vuosirajaa. Sekä kvalitatiiviset, että kvantitatiiviset ja teoreettiset aineistot otettiin mukaan. Aineiston tuli käsitellä CPC-CBT -menetelmää koskevia tutkimustuloksia. Monentyyppinen aineisto mahdollisti mahdollisimman kattavan kuvan saamisen menetelmästä.

Hakusanoiksi päätyivät "CPC-CBT" ja "Combined Parent Child Cognitive Behavioral Therapy". Hakusana "CPC-CBT" toi osuvat tulokset hakusanan "Combined Parent Child Cognitive Behavioral Therapy" tuodessa hallitsemattoman määrän aineistoon kuulumattomia tuloksia. Hakutulosten ollessa kohtuuttoman suuret, kuten Social Science Database 8714, Sociology Database 5053 ja Turun yliopiston kirjaston Volterin artikkelihaussa 18788 , jätettiin ne läpikäymättä. Aineiston muodostumisen vaiheet on esitetty taulukossa kaksi (Taulukko 2). Aineistoon saaduista teksteistä luettiin 38 jul- 
kaisua. Niistä 26 osumaa päätyi tulostettavaksi ja tarkempaan tarkasteluun sekä ydinkohtineen taulukoitavaksi. Tutkimukseen valikoitui mainituista 26 julkaisusta lopulta 17 tekstiä (Taulukko 3). Aineistoon sisällytetyt tutkimukset oli tehty joko Ruotsissa tai Yhdysvalloissa. Aineiston ulkopuolelle jäivät menetelmää, sen kehittämistä ja sisältöjä esittelevät artikkelit, rekisteriseloste, käsikirja menetelmästä sekä artikkelit, joissa CPCCBT oli mainintana.

Aineiston järjestämisen ja lukemisen (33) yhteydessä aineisto jakaantui kahteen kategoriaan.
CPC-CBT -työmuotoon ja sen asiakastyön tutkimuksiin ja raportteihin liittyviä aineistoja oli 10. Toisena ryhmänä oli seitsemän kirjallisuuskatsausta, joiden yhtenä aineistona oli CPC-CBT -työmuotoa koskeva tutkimus. Aineiston aihealueita koodattiin alleviivaamalla teksteihin ja kirjoittamalla niitä samalla alustaviin teeman mukaisiin ryhmiin. Koodeja ja teemoja oli helppo muodostaa, koska osa aineistosta sisälsi valmiita teemoja tai ne olivat helposti hahmoteltavissa. (Taulukko 4)

Taulukko 2. Aineiston muodostumisen vaiheet

\begin{tabular}{|c|c|c|c|c|c|c|}
\hline Tietokanta & Hakutermi & $\begin{array}{l}\text { Haun } \\
\text { tulokset }\end{array}$ & $\begin{array}{c}\text { Abstraktien } \\
\text { lukemiseen } \\
\text { valittu }\end{array}$ & $\begin{array}{c}\text { Koko teksti } \\
\text { luettu }\end{array}$ & $\begin{array}{l}\text { Koko teksti } \\
\text { tulostettu } \\
\text { ja luettu }\end{array}$ & $\begin{array}{l}\text { Valittu } \\
\text { aineisto }\end{array}$ \\
\hline \multirow{2}{*}{$\begin{array}{l}\text { Academic } \\
\text { Search } \\
\text { Premier }\end{array}$} & CPC-СBT & 4 & 4 & 4 & 4 & 3 \\
\hline & $\begin{array}{l}\text { Combined Parent } \\
\text { Child Cognitive } \\
\text { Behavioral Therapy }\end{array}$ & 12 & 12 & - & - & . \\
\hline \multirow{2}{*}{$\begin{array}{l}\text { SocINDEX } \\
\text { with Fulltext }\end{array}$} & CPC-CBT & 3 & 3 & 3 & - & . \\
\hline & $\begin{array}{l}\text { Combined Parent } \\
\text { Child Cognitive } \\
\text { Behavioral Therapy }\end{array}$ & 8 & 8 & - & - & - \\
\hline \multirow{2}{*}{$\begin{array}{l}\text { Social } \\
\text { Science } \\
\text { Database }\end{array}$} & CPC-CBT & 2 & 2 & 1 & 1 & 1 \\
\hline & $\begin{array}{l}\text { Combined Parent } \\
\text { Child Cognitive } \\
\text { Behavioral Therapy }\end{array}$ & 8714 & - & - & - & - \\
\hline \multirow{2}{*}{$\begin{array}{l}\text { Sociology } \\
\text { Database }\end{array}$} & СРC-СBT & 2 & 2 & 2 & - & - \\
\hline & $\begin{array}{l}\text { Combined Parent } \\
\text { Child Cognitive } \\
\text { Behavioral Therapy }\end{array}$ & 5053 & - & - & - & - \\
\hline \multirow[t]{2}{*}{ Scopus } & CPC-CBT & 6 & 6 & 4 & - & - \\
\hline & $\begin{array}{l}\text { Combined Parent } \\
\text { Child Cognitive } \\
\text { Behavioral Therapy }\end{array}$ & 226 & 226 & 1 & 1 & 1 \\
\hline \multirow{2}{*}{$\begin{array}{l}\text { Google } \\
\text { Scholar }\end{array}$} & СРC-СBТ & 87 & 87 & 17 & 14 & 6 \\
\hline & $\begin{array}{l}\text { Combined Parent } \\
\text { Child Cognitive } \\
\text { Behavioral Therapy }\end{array}$ & 73 & 73 & - & - & - \\
\hline \multirow{2}{*}{$\begin{array}{l}\text { Volter } \\
\text { artikkelihaku }\end{array}$} & СРC-СBТ & 39 & 39 & 6 & 6 & 6 \\
\hline & $\begin{array}{l}\text { Combined Parent } \\
\text { Child Cognitive } \\
\text { Behavioral Therapy }\end{array}$ & 18788 & - & - & - & - \\
\hline \multicolumn{4}{|c|}{ Koko tekstin lukemiseen päätynyt aineisto } & 38 & 26 & 17 \\
\hline
\end{tabular}


Taulukko 3. Katsaukseen sisällytetty aineisto

\begin{tabular}{|c|c|c|c|}
\hline $\begin{array}{l}\text { Tutkimuksen tai raportin tekijät, } \\
\text { vuosi, nimi }\end{array}$ & Tarkoitus & Aineisto & \begin{tabular}{|l|} 
Tulokset, tuotos \\
CPC-CBT:n osalta \\
\end{tabular} \\
\hline $\begin{array}{l}\text { (13) Schneider SJ, Grilli SF, } \\
\text { Schneider JR. 2013. Evi- } \\
\text { dence-Based Treatments for } \\
\text { Traumatized Children and } \\
\text { Adolescents }\end{array}$ & $\begin{array}{l}\text { Katsaus lasten ja } \\
\text { nuorten traumoihin kes- } \\
\text { kittyneistä työmuodoista } \\
\text { käyttötarkoituksineen }\end{array}$ & $\begin{array}{l}12 \text { tutkimusta, muka- } \\
\text { na CPC-CBT:stä Runyon } \\
\text { ym.(2010) RCT -tutkimus }\end{array}$ & $\begin{array}{l}\text { - Lupaava työmuoto kuritusvä- } \\
\text { kivallan ja lasten traumaattisten } \\
\text { kokemusten hoitoon }\end{array}$ \\
\hline $\begin{array}{l}\text { (14) Dorsey S, McLaughlin KA, } \\
\text { Kerns SEU, ym. 2017. Evidence } \\
\text { Base Update for Psychosocial } \\
\text { Treatments for Children and } \\
\text { Adolescents Exposed to } \\
\text { Traumatic Events }\end{array}$ & $\begin{array}{l}\text { Katsaus lasten ja nuor- } \\
\text { ten traumakokemusten } \\
\text { psykososiaalisen hoidon } \\
\text { interventioista }\end{array}$ & $\begin{array}{l}37 \text { tutkimusta erilaisista } \\
\text { interventioista, CPC-CBT:sta } \\
\text { mukana Runyon ym. (2009) ja } \\
(2010)\end{array}$ & $\begin{array}{l}\text { - Tekijävanhemman osallis- } \\
\text { tuminen tukee tavoiteltuja } \\
\text { vaikutuksia } \\
\text { - Otokset ovat pieniä ja } \\
\text { seuranta-aika lyhyt } \\
\text { - EBP luokittelun tasolla 2: } \\
\text { lupaava }\end{array}$ \\
\hline $\begin{array}{l}\text { (15) Leenarts LEW, Diehle J, } \\
\text { Doreleijers TAH, ym. 2013. } \\
\text { Evidence-based treatments for } \\
\text { children with trauma-related } \\
\text { psychopathology as a result of } \\
\text { childhood maltreatment: } \\
\text { a systematic review } \\
\end{array}$ & $\begin{array}{l}\text { Katsaus lasten kaltoin- } \\
\text { kohtelun hoitoon } \\
\text { suunnatuista näyttöön } \\
\text { perustuvista interven- } \\
\text { tioista }\end{array}$ & $\begin{array}{l}33 \text { interventiota, joista yksi } \\
\text { CPC-CBT Runyon ym. (2010) }\end{array}$ & $\begin{array}{l}\text { - Pieni otos, puutteellinen } \\
\text { seurantatieto, melko suuri } \\
\text { keskeyttäneiden määrä } \\
\text { - Ainut katsaukseen sisältynyt } \\
\text { interventio, jota tarjottiin myös } \\
\text { ennaltaehkäisevästi vanhemmille }\end{array}$ \\
\hline $\begin{array}{l}\text { (19) Temcheff CE, Letarte MJ, } \\
\text { Boutin S, ym. 2018. Common } \\
\text { components of evidence-based } \\
\text { parenting programs for } \\
\text { preventing maltreatment of } \\
\text { school-age children }\end{array}$ & $\begin{array}{l}\text { Katsaus lasten kaltoin- } \\
\text { kohtelun hoitoon suun- } \\
\text { nattujen työmuotojen } \\
\text { osatekijöistä, joiden } \\
\text { avulla työntekijöiden } \\
\text { olisi helpompi valita per- } \\
\text { heelle sopiva työmuoto } \\
\end{array}$ & $\begin{array}{l}14 \text { näyttöön perustuvaa työ- } \\
\text { muotoa, yksi niistä CPC-CBT }\end{array}$ & $\begin{array}{l}\text { - CPC-CBT sisällytetty CEBC } \\
\text {-rekisteriin ja on näyttöön } \\
\text { perustuvien työmuotojen } \\
\text { luokituksessa "lupaava", mikä } \\
\text { katsauksen tekijöiden mukaan } \\
\text { merkittävää menetelmälle }\end{array}$ \\
\hline $\begin{array}{l}\text { (20) Vlahovicova K, Melendez- } \\
\text { Torres GJ, Leijten P, ym. } 2017 . \\
\text { Parenting Programs for the } \\
\text { Prevention of Child Physical } \\
\text { Abuse Recurrence: A Systematic } \\
\text { Review and Meta-Analysis }\end{array}$ & $\begin{array}{l}\text { Katsaus sosiaalisen } \\
\text { oppimisen teoriaan } \\
\text { perustuvien vanhem- } \\
\text { muustyöskentelyjen } \\
\text { vaikuttavuudesta }\end{array}$ & $\begin{array}{l}14 \text { tutkimusta, mukana Runyon } \\
\text { ym. (2010) }\end{array}$ & $\begin{array}{l}\text { - CPC-CBT:llä ei mainittavaa } \\
\text { eroa ruumiillisen kurituksen } \\
\text { vähenemisen osalta verrokki- } \\
\text { ryhmään nähden, pieni otos, } \\
\text { vaikuttavuuden näytössä } \\
\text { puutteita } \\
\end{array}$ \\
\hline $\begin{array}{l}\text { (21) Goldman Fraser J, Lloyd S, } \\
\text { Murphy R, ym. 2013. } \\
\text { A Comparative Effectiveness } \\
\text { Review of Parenting and } \\
\text { Trauma-Focused Interventions } \\
\text { for Children Exposed } \\
\text { to Maltreatment }\end{array}$ & $\begin{array}{l}\text { Katsaus eri interventioi- } \\
\text { den vaikutuksesta vä- } \\
\text { hentää kaltoinkohtelun } \\
\text { haitallisia vaikutuksia } \\
\text { alle } 14 \text {-v. lapsiin }\end{array}$ & $\begin{array}{l}17 \text { interventiota, mukana } \\
\text { CPC-CBT:stä Runyon ym. } \\
(2010)\end{array}$ & $\begin{array}{l}\text { - Erinomainen vähentämään } \\
\text { lasten traumaoireita } \\
\text { - Näyttö käyttäytymisen ja hen- } \\
\text { kisen terveyden kohentamiseksi } \\
\text { ja vanhempi-lapsi vuorovaiku- } \\
\text { tuksen osalta puutteellista }\end{array}$ \\
\hline $\begin{array}{l}\text { (23) Runyon MK, Deblinger } \\
\text { E, Schroeder CM. 2009. Pilot } \\
\text { Evaluation of Outcomes of } \\
\text { Combined Parent-Child } \\
\text { Cognitive-Behavioral Group } \\
\text { Therapy for Families at Risk for } \\
\text { Child Physical Abuse }\end{array}$ & $\begin{array}{l}\text { Esittelee CPC-CBT -mal- } \\
\text { lin ja pilottitutkimuksen } \\
\text { tulokset }\end{array}$ & $\begin{array}{l}\text { Strukturoitu tiedon keruu (BDI- } \\
\text { II, PAI, CBCL, CDI, K-SADS- } \\
\text { P/L PTSD,CTSPC, APQ) } \\
\text { ennen ja jälkeen työskentelyn } 12 \\
\text { vanhemman roolissa olleelta ja } \\
21 \text { lapselta. } \\
48 \% \text { vanhemmista fyysistä } \\
\text { väkivaltaa käyttäviä ja loput } \\
\text { riskin perheitä. }\end{array}$ & $\begin{array}{l}\text { - Vanhempien väkivalta ja ärty- } \\
\text { neisyys lapsia kohtaan vähentyi, } \\
\text { johdonmukaisuus kasvatuksessa } \\
\text { lisääntyi } \\
\text { - Lasten posttraumaattinen } \\
\text { stressi ja käyttäytymisen pulmat } \\
\text { vähentyivät }\end{array}$ \\
\hline $\begin{array}{l}\text { (24) Runyon MK, Deblinger E, } \\
\text { Steer RA. 2010. Group } \\
\text { Cognitive Behavioral Treatment } \\
\text { for Parents and Children } \\
\text { At-Risk for Physical Abuse: } \\
\text { An Initial Study }\end{array}$ & $\begin{array}{l}\text { Ainut satunnaistettu } \\
\text { kontrolloitu tutkimus } \\
\text { (RCT) CPC-CBT:n ja } \\
\text { vain vanhemmille suun- } \\
\text { natun CBT:n välillä. }\end{array}$ & $\begin{array}{l}\text { CPC-CBT -työskentelyn } 24 \\
\text { vanhempaa ja } 34 \text { lasta sekä } 20 \\
\text { vanhempaa Parent Only CBT:stä } \\
\text { (heillä } 26 \text { lasta). Strukturoidut } \\
\text { lomakkeet (CTS-PC, K-SADS- } \\
\text { P/L PTSD,APQ, CBCL ennen, } \\
\text { jälkeen ja } 3 \text { kk työskentelyn } \\
\text { päättymisestä }\end{array}$ & $\begin{array}{l}\text { - Molemmat menetelmät } \\
\text { lupaavia ruumiillisen kurituksen } \\
\text { vähenemiseksi } \\
\text { - CPC-CBT auttoi lasten } \\
\text { posttraumaattisiin oireisiin ja } \\
\text { paransi vanhemmuuden taitoja } \\
\text { verrokkiryhmään nähden } \\
\text { - Seurannassa vain vanhemmille } \\
\text { suunnattu työskentelyssä olleet } \\
\text { käyttivät vähemmän ruumiillista } \\
\text { kuritusta verrattuna CPC- } \\
\text { CBT:ssä olleisiin }\end{array}$ \\
\hline $\begin{array}{l}\text { (28) Santini PM, Williams LCA. } \\
\text { 2016. Parenting Programs to } \\
\text { Prevent Corporal Punishment: } \\
\text { A Systematic Review }\end{array}$ & $\begin{array}{l}\text { Katsaus vanhemmille } \\
\text { suunnatuista kaltoin- } \\
\text { kohtelun loppumiseen } \\
\text { tähtäävistä interven- } \\
\text { tioista }\end{array}$ & $\begin{array}{l}9 \text { tutkimusta, mukana } \\
\text { CPC-CBT:stä Runyon ym. } \\
\text { (2009) ja Kjellgren ym. (2013) }\end{array}$ & $\begin{array}{l}\text { - Pienet otokset, vertailevan } \\
\text { tutkimuksen puute } \\
\text { - Siirrettävyyden vaikeus Yhdys- } \\
\text { valloista Ruotsiin } \\
\text { - Tulokset hyviä molemmissa } \\
\text { tutkimuksissa }\end{array}$ \\
\hline
\end{tabular}




\begin{tabular}{|c|c|c|c|}
\hline $\begin{array}{l}\text { (34) Thulin J. 2015. Samtal } \\
\text { med barn och föräldral samt } \\
\text { KIBB behandlare, socialsekre- } \\
\text { terare och åklagare. Kirjassa } \\
\text { Svedin ym. Slutrapport: KIBB } \\
\text { projektet, 29-37 }\end{array}$ & $\begin{array}{l}\text { Käyttäjäkokemusten } \\
\text { esiin saaminen }\end{array}$ & $\begin{array}{l}\text { KIBB -projektin aikainen kysely } \\
18 \text { lapselle, } 24 \text { vanhemmalle ja } \\
31 \text { työntekijälle }\end{array}$ & $\begin{array}{l}\text { - Myönteiset käyttäjäkoke- } \\
\text { mukset } \\
\text { - Kysely tuo esiin huomioitavia } \\
\text { seikkoja ja kehittämiskohteita }\end{array}$ \\
\hline $\begin{array}{l}\text { (35) Thulin J, Kjellgren C, } \\
\text { Nilsson D. 2018. Children`s } \\
\text { experiences with an } \\
\text { intervention aimed to prevent } \\
\text { further physical abuse }\end{array}$ & $\begin{array}{l}\text { Esittelee lasten ko- } \\
\text { kemuksia CPC-CBT } \\
\text {-työskentelystä }\end{array}$ & $\begin{array}{l}20 \text { iältään 9-17 vuotiaan } \\
\text { CPC-CBT -työskentelyyn } \\
\text { osallistuneen lapsen haastattelu } \\
\text { työskentelyn päätyttyä }\end{array}$ & $\begin{array}{l}\text { - Lasten kokemuksen mukaan } \\
\text { työskentely on lapsikeskeistä, se } \\
\text { on auttanut vanhempia lopetta- } \\
\text { maan fyysisen väkivallan, lasten } \\
\text { ja vanhempien vuorovaikutus on } \\
\text { parantunut }\end{array}$ \\
\hline $\begin{array}{l}\text { (36) Kjellgren C, Svedin CG, } \\
\text { Nilsson D. 2013. Child Physical } \\
\text { Abuse - Experiences of } \\
\text { Combined Treatment for } \\
\text { Children and their Parents: } \\
\text { A pilot study }\end{array}$ & $\begin{array}{l}\text { Pilottitutkimus- } \\
\text { tulokset Ruotsin KIBB } \\
\text {-työmuodosta vuosina } \\
\text { 2010-2011 työskente- } \\
\text { lyssä olleiden osalta }\end{array}$ & $\begin{array}{l}\text { Strukturoitu tiedon keruu } \\
\text { (CDI,TSCC,BDI-II,CBCL, } \\
\text { K-SADS PTSD, APQ ennen ja } \\
\text { jälkeen CPC-CBT -työskentelyn, } \\
18 \text { perhettä, } 26 \text { aikuista ja } \\
25 \text { lasta. }\end{array}$ & $\begin{array}{l}\text { - Lupaava työskentely ruotsalai- } \\
\text { sessa kontekstissa } \\
\text { - Lasten ja vanhempien ma- } \\
\text { sentuneisuusoireet vähenivät } \\
\text { työskentelyn myötä, lasten } \\
\text { traumaoireet helpottuivat, van- } \\
\text { hempien väkivaltaisuus väheni } \\
\text { ja positiiviset vanhemmuustai- } \\
\text { dot lisääntyivät }\end{array}$ \\
\hline $\begin{array}{l}\text { (37) Thulin J, Kjellgren C. } 2017 . \\
\text { Treatment in Barnahus: Imple- } \\
\text { menting Combined Treatment } \\
\text { for Children and Parents in } \\
\text { Physial Abuse Cases }\end{array}$ & $\begin{array}{l}\text { Esittelee CPC-CBT } \\
\text {-työmuotoa ja ruotsa- } \\
\text { laista KIBB - mallinnus- } \\
\text { ta sekä tutkimustulokset } \\
\text { KIBB -työskentelystä }\end{array}$ & $\begin{array}{l}28 \text { perhettä, } 34 \text { lasta ja } 45 \\
\text { vanhempaa. Haastattelu ja } \\
\text { strukturoitu (TSCYC, APQ, } \\
\text { BDI, LYLES, TSCC) tiedon } \\
\text { keruu ennen työskentelyä, } \\
\text { työskentelyn päätyttyä ja } 6 \mathrm{kk} \\
\text { sen jälkeen }\end{array}$ & $\begin{array}{l}\text { - Lasten traumaoireet ja käytös- } \\
\text { pulmat helpottuivat, vanhem- } \\
\text { pien väkivalta kasvatuksessa } \\
\text { vähentyi, kasvatustaidot kohen- } \\
\text { tuivat, perheiden hyvinvointi } \\
\text { lisääntyi }\end{array}$ \\
\hline $\begin{array}{l}\text { (38) Kjellgren C, Nilsson D, } \\
\text { Thulin J. 2017. Implementering } \\
\text { av en strukturerad behandlings- } \\
\text { modell vid barnmisshandel - ett } \\
\text { tioårsperspektiv }\end{array}$ & $\begin{array}{l}\text { Esittelee KIBB -mallin } \\
\text { käyttöönottoa } \\
\text { ensimmäisen } 10 \text { vuoden } \\
\text { ajalta Ruotsissa }\end{array}$ & $\begin{array}{l}\text { käyttöönottoprosessin kuvaus } \\
\text { sekä tulokset kyselystä sosiaali- } \\
\text { työntekijöille }\end{array}$ & $\begin{array}{l}\text { - Näyttöön perustuvan työmuo- } \\
\text { don käyttöönotto on vuosia } \\
\text { kestävä prosessi } \\
\text { - Kyselyn mukaan sosiaali- } \\
\text { työntekijät uskoivat KIBB } \\
\text { - menetelmään ja ovat valmiita } \\
\text { satsaamaan sen käyttöön } \\
\end{array}$ \\
\hline $\begin{array}{l}\text { (39) Cares Institute. Child Abuse } \\
\text { Research Education \& Service. } \\
2010 . \\
\text { How to Implement Combined } \\
\text { Parent-Child Cognitive } \\
\text { Behavioral Therapy (CPC-CBT) }\end{array}$ & $\begin{array}{l}\text { Esittelee CPC-CBT } \\
\text {-työmuodon perustan: } \\
\text { työskentelyrakenne, } \\
\text { toteuttaminen käytän- } \\
\text { nössä, työskentelyn } \\
\text { edellytykset }\end{array}$ & $\begin{array}{l}\text { CPC-CBT:n luojien mallinnus } \\
\text { ja Runyon \& Deblinger } 2009 \text { ja } \\
2010 \text { tutkimukset taustalla }\end{array}$ & $\begin{array}{l}\text { Koottu perustieto työmuodosta } \\
\text { työntekijöille, organisaatioille ja } \\
\text { muille tahoille }\end{array}$ \\
\hline $\begin{array}{l}\text { (40) Söderlind Göthner Y. } 2015 . \\
\text { KIBB utbildningen. Kirjassa } \\
\text { Svedin ym. Slutrapport: KIBB } \\
\text { projektet, 39-41 }\end{array}$ & $\begin{array}{l}\text { Kokoaa kehittämistyö- } \\
\text { tä, ruotsalaisen KIBB } \\
\text {-koulutuksen luomisen } \\
\text { vaiheet, rakenteen ja } \\
\text { vaatimukset pääpiir- } \\
\text { teissään } \\
\end{array}$ & $\begin{array}{l}\text { KBB- projektin aikainen } \\
\text { kehitystyö }\end{array}$ & $\begin{array}{l}\text { - Menetelmäkoulutus on } \\
\text { edellytys työskennellä mallin } \\
\text { mukaisesti Ruotsissa }\end{array}$ \\
\hline $\begin{array}{l}\text { (41) Santa-Sosa EJ, Runyon } \\
\text { MK. 2014. Addressing Ethno- } \\
\text { cultural Factors in Treatment for } \\
\text { Child Physical Abuse }\end{array}$ & $\begin{array}{l}\text { Tuo esiin kulttuurisia te- } \\
\text { kijöitä, jotka tulee ottaa } \\
\text { huomioon CPC-CBT } \\
\text {-työskentelyssä }\end{array}$ & $\begin{array}{l}\text { Kolme lyhyttä kuvausta CPC- } \\
\text { CBT -työskentelystä eri kulttuu- } \\
\text { ritaustaisten perheiden kanssa }\end{array}$ & $\begin{array}{l}\text { - Useita huomioitavia seikkoja } \\
\text { CPC-CBT -työskentelyssä eri } \\
\text { kulttuuritaustaisten kanssa } \\
\text { - Työntekijöiden koulutuksessa } \\
\text { nämä seikat huomioitava }\end{array}$ \\
\hline
\end{tabular}

APQ - Alabama Parenting Questionnaire

BDI-II - Beck Depression Inventory

CBCL - Child Behavior Checklist

CDI - Children`s Depression Inventory

CTSPC - Parent-Child Conflict Tactics Scale

K-SADS-P/L PTSD - Kiddie Schedule for Affective Disorders and Schizophrenia for School-Aged children Present and Lifetime version-PTSD Section Postraumatic Stress Disorder Interview

LYLES- Linköping Youth Life Experiences Scale

TSCC - Trauma Symptom Checklist for Children

TSCYC - Trauma Symptom Checklist for Young Children

PAI - Parental Anger Inventory 
Taulukko 4. Tulosten jakautuminen eri teemoihin

\begin{tabular}{|l|l|l|l|l|}
\hline TEEMA & \multicolumn{2}{|l|}{ ALATEEMAT } \\
\hline Tulokset kokemuksista & $\begin{array}{l}\text { Lasten } \\
\text { kokemukset } \\
\text { CPC-CBT } \\
\text {-työskentelyyn } \\
\text { osallistumisesta }\end{array}$ & $\begin{array}{l}\text { Vanhempien } \\
\text { kokemukset } \\
\text { CPC-CBT } \\
\text {-työskentelyyn } \\
\text { osallistumisesta }\end{array}$ & $\begin{array}{l}\text { Työntekijöiden } \\
\text { kokemukset } \\
\text { CPC-CBT } \\
\text {-menetelmästä }\end{array}$ \\
\hline $\begin{array}{l}\text { Tulokset CPC-CBT } \\
\text {-työskentelyllä } \\
\text { tavoitelluista muutoksista }\end{array}$ & $\begin{array}{l}\text { Lasten esiin } \\
\text { tuomat } \\
\text { muutokset }\end{array}$ & $\begin{array}{l}\text { Vanhempien esiin } \\
\text { tuomat muutokset }\end{array}$ & $\begin{array}{l}\text { Työntekijöiden } \\
\text { esiin tuomat } \\
\text { muutokset } \\
\text { perheissä }\end{array}$ & $\begin{array}{l}\text { CPC-CBT } \\
\text {-työskentelymalli } \\
\text { kirjallisuuskatsauksissa }\end{array}$ \\
\hline $\begin{array}{l}\text { Työntekijöiden tietotaito- } \\
\text { vaatimukset aineistoon } \\
\text { sisältyvissä tutkimuksissa }\end{array}$ & - & \multicolumn{4}{|l|}{} & \\
\hline
\end{tabular}

\section{TULOKSET KOKEMUKSISTA}

\section{LASTEN KOKEMUKSET CPC-CBT -TYÖSKENTELYYN OSALLISTUMISESTA}

Tutkimusaineistossa lasten käyttökokemuksia CPC-CBT -työskentelystä oli ruotsalaisissa julkaisuissa. Saatavilla oli 18 lapselle tehty haastattelu (34) ja puolistrukturoitu kysely 20 lapselle (35). Saatavilla olleissa yhdysvaltalaisissa tutkimuksissa ei ole tutkittu lasten kokemuksia työmenetelmästä.

Lapset pitivät työskentelyn rakenteesta, jossa joka tapaamiskerralla työskennellään ensin lapset ja vanhemmat erikseen ja sitten lopuksi yhdessä. Työntekijän tutuksi tuleminen ja luottamuksen syntyminen auttoivat kertomaan omista huolista ja kokemaan turvallisuutta. Lasten mukaan työntekijä ymmärsi ja otti huomioon mahdollisen pelon ja huolen koskien perheen yhteistä tapaamista ja käsiteltäviä asioita. Tutkimuksen mukaan lasten kerronnasta kuvastui työskentelyn lapsiystävällisyys. (35.)

Myös työntekijän antama apu lapsille oli tärkeää, kun työskentelyn viimeisillä kerroilla lapset kirjoittivat kirjeen vanhemmilleen $(34,35)$. Kirjeen kirjoittaminen vanhemmille oli lasten mukaan vaikuttava osa työskentelyä. Kirjeessä lapset pystyivät kertomaan kokemuksistaan ja tunteistaan. Vanhempien vastatessa kirjeeseen tuli lapsille hyvä olo, ja se ikään kuin lähensi lapsia ja vanhempia entisestään. Osa lapsista kuuli ensi kerran vanhemman olevan pahoillaan sattuneesta ja myöntävän tehneensä väärin. Osa lapsista taas koki, että kokemuksista kirjoittaminen toi ikävällä tavalla mieleen kokemukset, mutta apu työntekijältä auttoi ja kirjoittamisen jälkeen oli helpottunut olo. (35.)
Lapset kommentoivat, että tapaamisissa oli mukavaa, vaikka ennen tapaamisiin lähtöä ei olisi halunnut lähteä mukaan. Tapaamisiin meni paljon aikaa, ja harrastuksia jäi väliin. Pelaaminen, kortit ja muut tunteiden käsittelyn välineet sekä se, että sai puhua aikuisen kanssa, syödä ja leikkiä, olivat lasten mukaan työskentelyssä mukavia asioita. Tapaamiset koettiin myös perheen viettämäksi yhteiseksi ajaksi. Yhtäl̈ltä lapset saivat puhua kotioloista vapaasti, mutta toisaalta heidän piti erityisesti puhua vaikeista asioista. Työskentelyssä lapset oppivat, että tehdyn turvasuunnitelman kautta voi itse myös vaikuttaa kodin ristiriitatilanteiden etenemiseen ja että kotioloista saa kertoa. (34.)

\section{VANHEMPIEN KOKEMUKSET CPC-CBT -TYÖSKENTELYYN OSALLISTUMISESTA}

Vanhempien käyttökokemuksia CPC-CBT -työmenetelmästä on saatu Ruotsissa 24 vanhemman kanssa käydyistä keskusteluista, mitkä toteutettiin kunkin vanhemman CPC-CBT -työskentelyn jälkeisessä tapaamisessa (34). Muita tutkimuksia vanhempien kokemuksista ei ollut saatavilla.

Työntekijän tapa työskennellä ja suhteen muodostuminen työntekijään saivat huomiota vanhemmilta. Vanhemmat kokivat, että apua saatiin nopeasti ja oli mahdollisuus puhua tuomitsemattomassa, vanhempaa arvostavassa ilmapiirissä. Työskentely koettiin pituudeltaan hyväksi, ja viikoittaiset tapaamiset saivat pysymään kiinni työskentelyprosessissa. Kokonaisuus koettiin hyväksi. Toteutuksen rakenne toi perheelle yhteistä aikaa, siihen sisältyi iloa ja lasten kanssa puhumista. Työskentely opetti vanhempia ajattelemaan uudella tavalla ja auttoi heitä näkemään lapsensa uudesta näkökulmasta. (34.) 
Osa vanhemmista koki, että työskentely vei aikaa ja oli liian pitkäkestoista. Osallistuminen oli vanhemmille stressaavaa, ja he kokivat olevansa jaksamisensa äärirajoilla. Yhteistyötä muiden toimijoiden kanssa olisi toivottu enemmän, samoin tietoa kuritusväkivaltaan liittyvien oikeusprosessien kulusta. Pitkittyminen ja tietämättömyys oikeusprosessin etenemisestä veivät aikaa vanhempien ajatuksissa ja olivat häiriötekijä työskentelyssä. Kaivattiin tietoa siitä, mihin kriisitilanteissa voi ottaa yhteyttä keskusteluavun saamiseksi. Osa vanhemmista koki työskentelyssä olleen liikaa toistoa, ja osa koki lopputuloksen heikkona, kun ongelmat jatkuivat. Keinottomuus vanhempana turhautti, kun kinastelevia lapsia ei saanut fyysisesti erottaa toisistaan. Vanhemmat kokivat turvasanan toimivaksi keinoksi ja toivoivat sen esilletuloa aikaisemmassa työskentelyvaiheessa, jotta sen harjoitteluun olisi enemmän aikaa. (34.)

Eräs vanhempi kiinnitti huomiota työmuodon nimeen ja koki ikävänä, kun nimessä on sana kaltoinkohtelu. Lukujärjestys teemoista olisi vanhempien mukaan auttanut hahmottamaan työskentelyn etenemistä. Osalla vastanneista oli kokemusta ryhmämuotoisesta työskentelystä, vaikka perhekohtainen työskentely oli yleisintä. Ryhmä toi mahdollisuuden tavata samassa tilanteessa olevia perheitä. Osalle ryhmämuotoinen toiminta ei ollut hyvä kokemus, sillä ryhmässä oli liian erilaisia perheitä ja sen vuoksi oli hankalaa yhdistää eri ongelmia työskentelyyn. (34.)

\section{TYÖNTEKIJ̈IIDEN KOKEMUKSET CPC-CBT -TYÖSKENTELYSTÄ}

Ruotsissa 31 CPC-CBT -työskentelyyn osallistunutta työntekijää (ammattitaustoja ei mainittu) vastasi avoimista kysymyksistä koostuvaan kyselyyn kokemuksista joko koulutustapaamisissa tai sähköpostitse (34). Työntekijät arvioivat itse, oliko heillä riittävää kokemusta menetelmästä vastata kysymyksiin.

Työntekijöiden mielestä työskentelyn teemat olivat hyviä. Teemoissa käsiteltiin selkeästi väkivaltaa, rajojen ylittämistä sekä kasvatuksellisia asioita. Väkivalta pysyi keskiössä ja työskentely oli lapsiystävällistä. Avoimuus ja tuomitsemattomuus työskentelyssä loivat kunnioittavaa ilmapiiriä. Koko perheen osallistuminen työskentelyyn auttoi puhumaan vaikeista asioista ja nosti lasten näkökulman keskiöön. Työntekijöiden mielestä vanhemmat saivat apua väkivaltaisuu- teen, lapset traumaoireisiin ja perheenjäsenet puhuivat vaikeistakin asioista keskenään. Vanhemmat ottivat vastuuta väkivaltaisesta käytöksestään sekä perheen turvallisuudesta. Hyvänä asiana pidettiin sitä, että vaikka työskentelyssä on selkeä rakenne, voi sitä kuitenkin muokata kunkin perheen tarpeita vastaavaksi. (34.)

Hankaluutena työntekijät toivat esille työmuotoa koskevan materiaalin liiallisen ohjaavuuden. Ohjeistus oli aluksi vaikea ja epäselvä. Jotkut työskentelyn osat veivät enemmän aikaa, mitä ohjeessa kerrotaan. Puutteena oli myös, että työskentelyä ei ole muokattu pienempien lasten tarpeita vastaavaksi. Itse työskentely vei paljon aikaa ja työntekijäresursseja. Tämä asetti myös vaatimuksia työntekijöiden yhteistyölle ja keskinäiselle kommunikoinnille. Työntekijöiden huolina oli, miten vanhemmat saa jatkamaan oppimaansa työskentelyn päätyttyä ja miten paljon vanhemman kognitiiviset vaikeudet vaikuttavat oppimiseen. Työntekijöiden mielestä osa perheistä kaipaisi työskentelyn lisänä konkreettista, täydentävää apua kotiin. (34.)

Ruotsissa on tehty myös kysely CPC-CBTtyöskentelyssä olleita perheitä kohdanneille sosiaalityöntekijöille. Kyselyyn vastasi 14 sosiaalityöntekijää. Kyselyyn vastanneet sosiaalityöntekijät pitivät CPC-CBT:tä parempana tai paljon parempana kuin muut aiemmat työskentelymuodot lasten kaltoinkohtelun loppumiseksi. Heidän mukaansa lapset ja vanhemmat olivat pitäneet työskentelystä. Sosiaalityöntekijät olivat sitä mieltä, että he todennäköisesti satsaisivat tähän työmuotoon silloin, kun perheessä on lasten kaltoinkohtelua. (38.)

\section{TULOKSET CPC-CBT -TYÖSKENTELYLLÄ TAVOITELLUISTA MUUTOKSISTA}

\section{LASTEN ESIIN TUOMAT MUUTOKSET}

Tutkimustulokset lasten esiin tuomista CPC-CBT -työskentelyn muutoksista on saatu Yhdysvalloissa $(23,24)$ ja Ruotsissa $(36,37)$ strukturoiduilla kyselylomakkeilla tehdyillä tutkimuksilla. Tutkimusaineistoista ei käy ilmi, että tuloksia arvioitaessa olisi hyödynnetty myös viranomaistietoa, kuten lastensuojelu- ja rikosilmoitustietoja. Ruotsissa koettua muutosta on tutkittu myös kyselyjen $(34,35)$ avulla. Avointen kysymysten vastauksissa $(34,35)$ vastaajien tarkoittama väkivallan muoto jää osin epäselväksi. 
Lasten kokemuksia selvittäneiden tutkimusten mukaan fyysinen väkivalta oli joko vähentynyt tai kokonaan loppunut perheissä. Tähän liittyvät myös perheen vuorovaikutuksen ja kodin ilmapiirin paraneminen sekä muuttuneet kasvatuskäytännöt. (23,24,34-37.) Perheissä riidellään vähemmän, puhutaan enemmän ja kotona on enemmän leikkiä ja yhdessäoloa. Lapset huomioivat, että vanhemmat oppivat uusia taitoja lasten kasvatukseen ja oman vihansa hillitsemiseen sekä konkreettisia keinoja rauhoittua. Lapset uskoivat tämän muutoksen pysyvyyteen. $(34,35$.)

Huomioitavaa oli, että lapset toivat ilmi ennen työskentelyä vallinneen ruumiillisen kurittamisen yleisempänä kuin vanhemmat työskentelyn alussa (37). Osa lapsista kommentoi, että työskentelystä huolimatta apu ei riittänyt perheelle ja osalla vanhemman fyysinen väkivalta muuttui muuksi kaltoinkohteluksi (34).

Lasten posttraumaattisten oireiden helpottuminen on esitetty CPC-CBT -työskentelyn tuomana hyötynä $(23,24,36,37)$. Satunnaistettu kontrolloitu tutkimus vain vanhemmille suunnatun CBT -työskentelyn ja CPC-CBT -työskentelyn välillä toi esiin, että lasten posttraumaattiset oireet helpottuivat paremmin työskentelyssä mukana olevilla lapsilla kuin vain vanhemmille suunnatussa työskentelyssä olleiden perheiden lapsilla. CPC-CBT -työskentelyssä vaikuttavana tekijänä on tutkimuksen tekijöiden näkemyksen mukaan traumanarratiivin tekeminen ja vanhempien kanssa lopuksi käyty selkiyttävä työskentely. (24.) Lasten masentuneisuuden helpottumisesta CPC-CBT -työskentelyn myötä oli myös näyttöä $(23,36,37)$.

Lapset toivat ilmi, että he oppivat työskentelyssä keinoja selviytyä kokemuksista ja käsitys itsestä ja vanhemmista parani $(34,36)$. Riitoja tuli vähemmän vanhempien ja sisarusten kanssa, koulu meni paremmin ja itsearvostus lisääntyi (34). Kuunteleminen ja toisten ihmisten näkökulmien huomioiminen lisääntyivät ja tunteiden ilmaisu parantui. Ne lapset, joilla oli ollut oman käytöksensä kontrolloinnissa vaikeuksia ennen työskentelyä, kertoivat saaneensa keinoja rauhoittua. $(34,35$.)

\section{VANHEMPIEN ESIIN TUOMAT MUUTOKSET}

Tutkimustulokset vanhempien esiin tuomista CPC-CBT -työskentelyn muutoksista on saatu
Yhdysvalloissa $(23,24)$ ja Ruotsissa $(36,37)$ strukturoiduilla kyselylomakkeilla tehdyillä tutkimuksilla. Tutkimusaineistoista ei käy ilmi, että tuloksia arvioitaessa olisi hyödynnetty myös viranomaistietoa, kuten lastensuojelu- ja rikosilmoitustietoja. Ruotsissa koettua muutosta on tutkittu myös kyselyn (34) avulla.

Vanhemmat kokivat, että työskentelyn tuloksena heidän tekemänsä ruumiillinen kuritus loppui kokonaan tai väheni huomattavasti. He huomioivat oman epäjohdonmukaisuutensa vähentyneen vanhemmuudessa. Myös tunteiden säätely parani ja vihan tunne hankalissa tilanteissa lasten kanssa väheni. (23,24,34,36,37.) Vanhempien lapsiinsa kohdistaman ruumiillisen kurituksen ilmentymiä ennen työskentelyä on tutkimuksissa $(23,24,36,37)$ tuotu esiin, mutta tuloksista ei ole nähtävillä, mitä ruumiillisen kurituksen muotoja on jäänyt jäljelle niissä tapauksissa, joissa kaltoinkohtelu ei ole loppunut, vaan vähentynyt.

Vanhempien käytös muuttui heidän oman arvionsa mukaan myös lapsille ennalta-arvattavammaksi. Suhde lapsiin parani ja vuorovaikutus lisääntyi. Tästä huolimatta vanhemmat raportoivat, etteivät heidän positiiviset kasvatuskäytäntönsä ole heidän omasta mielestään lisääntyneet. (37.) Lapset sen sijaan raportoivat, että tässä on tapahtunut muutosta (35).

Vanhemmat näkivät työskentelyn tuomaa muutosta lapsissaan sekä lomakekyselyjen että käytyjen keskustelujen perusteella. Vanhempien mukaan lasten käyttäytymisessä ja voinnissa tapahtui työskentelyn myötä muutosta parempaan $(23,36,37)$. Vanhemmat kertovat myös rauhallisemmasta kotielämästä. Lapset ovat rauhallisempia ja luottavat vanhempaansa enemmän. Lasten on helpompi ilmaista tunteitaan, ja lapset tietävät oikeuksistaan enemmän. (34.)

\section{TYÖNTEKIJÖIDEN ESIIN TUOMAT MUUTOKSET PERHEISSÄ}

Ruotsissa CPC-CBT -työskentelyyn osallistuneista työntekijöistä 31 vastasi laadittuihin avoimiin kysymyksiin näkemyksistään työskentelyn vaikutuksista (34). Vastaavanlaista tutkimusta USA:sta ei aineistosta löytynyt.

Työntekijät näkivät positiivista muutosta vanhemmissa. Heidän mukaansa vanhemmat oppivat työskentelyn aikana kommunikoimaan enemmän, olivat tietoisempia lastensa tarpeista ja pystyivät katsomaan asioita lasten näkökulmasta. Vanhemmat toimivat paremmin yhdessä ja yh- 
teistyössä lasten kanssa. Vanhemmat omaksuivat uusia keinoja lasten kanssa toimimiseen, ja ilmapiiri perheissä muuttui avoimemmaksi. Lasten kehumista opittiin, ja väkivallankäyttö loppui tai vähentyi perheissä. Väkivallasta puhuminen oli helppoa vanhempien kanssa joitakin poikkeuksia lukuun ottamatta. Puhumisen helppous tai vaikeus riippui siitä, kuinka avoimia vanhemmat olivat ja millainen lupa lapsilla oli siitä todella puhua. Vanhempien kognitiivisten pulmien ja perheiden moninaisten ongelmien vaikutus työskentelystä saatuun hyötyyn mietitytti vastanneita työntekijöitä. (34.)

\section{CPC-CBT -TYÖSKENTELYMALLI KIRJALLISUUSKATSAUKSISSA}

Tutkimusaineistoon sisältyi 7 kirjallisuuskatsausta, joissa tutkittiin väkivaltaa kokeneiden ja traumatisoituneiden lasten sekä heidän vanhempiensa auttamiseksi tarkoitettuja näyttöön perustuvia menetelmiä. Kussakin kirjallisuuskatsauksessa yhtenä aineistona oli CPC-CBT -menetelmä tai sitä koskeva tutkimus. Katsauksissa tarkasteltiin lähinnä menetelmien vaikuttavuutta, siirrettävyyttä ja käytettävyyttä. Sisällölliset erot, menetelmien rakenne ja työskentelyä ohjaavat periaatteet olivat osin myös esillä.

Lasten ja nuorten traumakokemusten hoitoon tarkoitettujen menetelmien kirjallisuuskatsauksessa (14) vaikuttavuus oli luokiteltu seuraavasti: hyvin toteen näytetty, todennäköisesti vaikuttava, mahdollisesti vaikuttava ja kokemusperäinen menetelmä. CPC-CBT luokiteltiin todennäköisesti vaikuttavaksi. Tutkijoiden mukaan CPC-CBT tukee käsitystä siitä, että vanhempien ja lasten osallistuminen työskentelyyn yhdessä on toimivaa. (14.) CPC-CBT:n luokittelu lupaavaksi työmuodoksi California Evidence-Based Clearinghouse -rekisterissä nähtiin hyvänä näyttönä menetelmästä (19).

CPC-CBT oli yhdessä kirjallisuuskatsauksessa ainut työmuoto, jota tarjottiin myös kaltoinkohtelun riskissä oleville vanhemmille. Menetelmän käytettävyyttä ennaltaehkäisevänä työmuotona kirjoittajat pitävät hyvin tärkeänä asiana lasten ruumiillisen kurituksen ehkäisemiseksi. (15.) Myös mahdollisuutta työskentelyn räätälöimiseen perheiden tarpeiden mukaan pidettiin hyvänä ominaisuutena (28). Kirjallisuuskatsauksissa CPC-CBT -työskentelymalli nähtiin tärkeänä työmuotona vähentämään lasten posttraumaattisia oireita $(13,21)$. Sen nähtiin vähentävän kuritusväkivaltaa ja parantavan vanhempien käytöstä ja suhdetta lapsiin. Lasten ja vanhempien kokemat masentuneisuusoireet vähenivät ja hyvinvointi lisääntyi. (28.) Eroa ruumiillisen kurituksen vähenemisessä CPC-CBT:n ja vain vanhemmille suunnatun $\mathrm{CBT}$ välillä pidettiin vähäisenä. Katsauksessa huomioitiin, että CPC-CBT:ssä jäi vähemmän aikaa vanhemmuuden taitojen harjoittelemiseen. (20.)

CPC-CBT:tä koskevien tutkimusten puutteena tuotiin esille pilottitutkimuksista johtuva testiryhmien pieni koko ja pitkän ajan seurannan puutteet osoittaa vaikuttavuutta $(14,15,20,28)$. Sama tuodaan esille myös niissä tutkimuksissa, jotka oli sisällytetty kirjallisuuskatsauksiin (23, 24,36,37). Työmuodon siirrettävyys itsessään Yhdysvalloista Ruotsiin nähtiin haasteellisena, sillä määritelmä lasten fyysisestä väkivallasta ja lasten kohtaaman väkivallan kiellettävyydestä eroaa yhdysvaltalaisen ja ruotsalaisen kulttuurin ja yhteiskunnan välillä (28). Näitä eroja ei tutkimuksissa tarkennettu. Ruotsin pilottitutkimuksen kokemusten mukaan CPC-CBT on haasteista huolimatta yleisesti ottaen siirrettävissä kulttuurisesti erilaiseen kontekstiin (36). Suhteellisen korkeaan keskeyttäneiden määrään kiinnitettiin myös huomiota (15). Toisaalta menetelmän kehittäjät ovat huomioineet, että työskentelyn keskeyttäneiden määrä on alhainen työskentelyn alkuun kuuluvan sitouttamistyöskentelyn jälkeen (24).

\section{TYÖNTEKIJÖIDEN TIETO-TAITOVAATIMUKSET TUTKIMUSAINEISTOON SISÄLTYVISSÄ TUTKIMUKSISSA}

Katsaukseemme sisällytetyissä tutkimuksissa oli tarkasteltu CPC-CBT -työskentelyä toteuttavilta työntekijöiltä vaadittavia tiedollisia ja taidollisia vaatimuksia, vaikka osaamisvaatimukset eivät sinänsä ole tutkimusten kohteena. Tämä tieto on tärkeää tuoda esiin menetelmän käyttöönoton kannalta. Tämän vuoksi otimme kirjallisuuskatsaukseemme myös työntekijöiden tietotaitovaatimuksia tarkemmin käsittelevän menetelmäohjeistuksen (39) ja ruotsalaista koulutusta käsittelevän artikkelin (40).

Pohjakoulutukseltaan Yhdysvalloissa CPCCBT:n työntekijöinä mainitaan psykologeja ja maisteritason sosiaalityöntekijöitä (24). Ruotsissa menetelmän käyttöönoton alullepanijoina ja ensimmäisinä kouluttautujina oli sosiaalityöntekijöitä (38). Myöhemmin työntekijöinä on ollut 
myös lastensuojelun sekä lasten- ja nuorisopsykiatrian työntekijöitä, jotka ovat saaneet lisäkoulutusta kognitiivis-behavioraaliseen työskentelyyn (36). Tieto ja ymmärrys kognitiivis-behavioraalisen työskentelyn periaatteista ovat eduksi menetelmään kouluttautujilla (23).

Menetelmän käytön edellyttävästä koulutuksesta on Yhdysvalloissa esitetty erilaisia pituuksia kahdesta koulutuspäivästä $(23,24)$ kolmeen kahden päivän koulutuspäivään, joihin sisältyy työskentelyprosessin konsultaatiotukea (39). Ruotsissa ensimmäiset työntekijät kouluttautuivat työskentelyyn mallin kehittäjän, Runyonin, kouluttamana (36). Sittemmin Stiftelsen Allmänna Barnhuset (säätiö, joka tekee vaikuttamistyötä, tukee tutkimusta ja lasten hyväksi kehitettävien menetelmien käyttöä) on luonut 11 päivän koulutusrakenteen työskentelyprosessin aikaisella konsultaatiotuella (40).

Ruotsissa koulutukseen tulevan työntekijän vaatimuksina ovat käyttäytymistieteellinen tai vastaava korkeakoulututkinto, kokemus työskentelystä lasten ja perheiden kanssa sekä hyvä tietämys siitä, mitä manuaaliin pohjautuva työskentely sisältää. Toivottavina ominaisuuksina pidetään kokemusta työskentelystä väkivaltatyössä, kykyä puhua väkivallasta, kokemusta kognitiivis-behavioraalisesta menetelmästä, kiinnostusta oppia uutta ja uskallusta kohdata vanhempia ja lapsia luovasti ja joustavasti. (40.)

Samalle paikkakunnalle tulee kouluttaa vähintään kolme työntekijää, jotta työntekijäresursseja vaativa työskentely pysyisi yllä työntekijävaihdoksista huolimatta (40). Rekrytointivaiheessa työntekijät tarvitsevat selkeää tietoa menetelmästä osallistumispäätöksensä tueksi $(29,39)$ menetelmän käytön hylkäämisen minimoimiseksi (38). Koulutuksen tulee sisältää laajaa tietoa työmenetelmästä, taustalla olevista teorioista ja arvoista, tietoa ilmiöstä vaikutuksineen ja käytännön harjoittelua (39). CPC-CBT edellyttää koulutusten, kehittämisen ja ylläpidon toteutumiseksi vankan ammatillisen osaamisen ja rakenteen. Työntekijöiden tulee myös verkostoitua ja hankkia lisäkoulutusta. (38.)

CPC-CBT -työskentelyyn on osallistunut eri kulttuuritaustaisia perheitä $(23,36,37)$. Yksi artikkeli toi kolmen eri työskentelytapauksen kautta esiin, mihin työntekijällä tulee olla valmiuksia maahanmuuttajataustaisten perheiden parissa toteutettavassa CPC-CBT -työskentelyssä (41). Val- miudet ovat pitkälti samoja kuin kulttuuritietoisessa asiakastyössä yleisemmin.

Työntekijän tulee joustavasti huomioida, että käytetty kieli on perheelle ymmärrettävää. Kieltä tulee käyttää niin, että se huomioi perheen sosiokulttuurisen kontekstin. Tulkin käytöstä on sovittava perheen kanssa yhdessä ja sallittava työskentelyn aikana myös useiden kielten käyttö. Leimaavien ilmaisujen välttämiseksi työntekijän on tutustuttava kulttuurisiin erityispiirteisiin. Työntekijän kiinnostuneisuus oppia tuntemaan perheen kulttuuria ja sitä, mitä tämä kulttuuri juuri tälle perheelle merkitsee, on tärkeää. Oman persoonan käyttö ja keskustelut kulttuurisista samankaltaisuuksista ja eroavaisuuksista luovat tuttuutta. Kotikäynti voi olla yksi väylä päästä osaamisessa syvemmälle. Lähtökohtana on, että perhe on oman kulttuurinsa asiantuntija. (41.)

Lasten kuritusväkivaltaan ja vanhempien omiin lapsuudenkokemuksiin liittyvistä ajatuksista on syytä keskustella ja liittää siihen kulttuurisista uskomuksista, arvoista ja uskontoon liittyvistä käsityksistä nousevia seikkoja. Tiedon antaminen maan lainsäädännöstä ja lasten kasvatukseen liittyvistä käsityksistä kuuluvat työskentelyyn. CPC-CBT -työskentelyn raamittaminen tukeen, perheen tapaan kasvattaa lapsia ja kulttuurisiin tekijöihin on tärkeää. Keskustelut sekä lasten että vanhempien kanssa auttavat heitä prosessoimaan erilaisissa kulttuurisissa ympäristöissä elämiseen liittyviä kokemuksia. Työntekijän joustavuus työskentelyn konkretisoimisessa on tärkeää. (41.)

Menetelmän kehittäjän mukaan työntekijät ovat hyödyntäneet omaksumaansa CPC-CBT:n osaamista myös muussa asiakastyössään ja uusi työmuoto on vaikuttanut koko organisaation tapaan työskennellä $(25,26)$.

\section{JOHTOPÄÄTÖKSET}

Tavoitteenamme oli kuvailevan kirjallisuuskatsauksen avulla saada tietoa CPC-CBT -menetelmän kansainvälisistä tutkimustuloksista. Tieto siitä, miten työmuotoa on käytetty perheiden kanssa tehtävässä väkivaltatyössä ja millaisia kokemuksia lapsilla, vanhemmilla ja työntekijöillä on CPC-CBT:n käytöstä on tärkeää arvioitaessa menetelmän käytettävyyttä Suomessa.

CPC-CBT sai tutkimusten mukaan hyvää palautetta lapsilta, vanhemmilta sekä työskentelyyn osallistuneilta ja perheitä kohdanneilta 
työntekijöiltä. Työskentely oli hyödyllistä perheille, ja työskentelyrakenteesta pidettiin. Oman työntekijän luoma luottamuksellinen ja turvallinen suhde lapseen ja vanhempaan oli tärkeää. Työntekijä auttoi, huomioi hankalat tilanteet ja suojasi lasta haitallisilta kokemuksilta. Työskentelyssä pystyttiin puhumaan perheenjäsenten kesken väkivallasta. $(34,35$.) Tapaamiset olivat perheen yhdessä viettämää aikaa ja niihin koettiin sisältyneen iloa. Pitkä työskentely vei paljon aikaa ja vaati perheeltä järjestelyjä. Osa vanhemmista koki työskentelyn riittämättömänä ja olisi kaivannut enemmän omia tarpeitaan vastaavaa työskentelyä. (34.)

Työntekijät pitivät työskentelystä, uskoivat sen tuloksiin - ja kokivat hyödyllisenä, että koko perhe on samassa työskentelyssä (34). Työskentelyyn sisältyvien asioiden runsaus, ajan puute ja perhekohtaisen muokkaamisen tarve tuotti hankaluuksia (34). Perheitä työskentelyyn lähettäneet sosiaalityöntekijät uskoivat CPC-CBT:n hyötyihin (38).

Tutkimustuloksista kävi ilmi, että tavoitteeseen, lasten vanhemmiltaan kohtaaman väkivallan loppumiseen oli useimmiten päästy. Kuritusväkivalta loppui tai väheni, lapset ja vanhemmat oppivat taitoja, vuorovaikutus parantui ja lasten posttraumaattiset oireet helpottivat. $(23,24$, 36,37.) Lapset oppivat vuorovaikutustaitoja ja oman käytöksen kontrollointia $(34,35)$.

Tutkimuksissa esitettiin lähtötilanteen fyysisen kuritusväkivallan ilmentymiä $(23,24,36,37)$, mutta epäselväksi jäi, mitä oli jäänyt jäljelle ja miten siihen oli puututtu tilanteissa, joissa lopputulemana oli väkivallan väheneminen. Osa lapsista ilmaisi fyysisen väkivallan muuttuneen muuksi kaltoinkohteluksi (34).

Vuoden 2010 tutkimus (24) Yhdysvalloista oli ainut menetelmää koskeva satunnaistettu kontrolloitu tutkimus. Ruotsissa vastaavaa tutkimusta ei pystytty toteuttamaan kontrolliryhmän saamiseen liittyvien vaikeuksien vuoksi (42). Satunnaistettu kontrolloitu tutkimus vain vanhemmille suunnatun CBT -työskentelyn ja CPC-CBT -työskentelyn välillä toi esiin, että molemmat menetelmät ovat lupaavia. Lasten posttraumaattiset oireet helpottuivat paremmin työskentelyssä mukana olevilla lapsilla. Vain vanhemmille suunnattu CBT vähensi kuritusväkivallan käyttöä enemmän, koska taitojen harjoitteluun jäi enemmän aikaa kuin CPC-CBT:ssä. (24) Kirjallisuuskat- sauksissa huomioitiin, että ruumiillisen kurituksen vähenemisessä ei ollut mainittavaa eroa verrokkiryhmään $(15,20)$.

Kirjallisuuskatsauksissa CPC-CBT -työskentelymalli nähtiin tärkeänä työmuotona vähentämään lasten posttraumaattisia oireita $(13,21)$. CPC-CBT:tä koskevien tutkimusten puutteena tuotiin esille pilottitutkimuksista johtuva testiryhmien pieni koko ja pitkän ajan seurannan puutteet vaikuttavuudesta $(14,15,20,28)$. CPCCBT -työmuoto huomioitiin lupaavaksi menetelmäksi $(13,21,28)$. Menetelmän rakenne, jossa lapset, tekijävanhempi ja väkivaltaa käyttämätön vanhempi ovat yhtäaikaisesti työskentelyssä, koettiin tärkeäksi (28). Työskentelyn mahdollisuus ennaltaehkäisevässä mielessä sai myös hyvää palautetta (15).

Tässä artikkelissa halusimme kiinnittää huomion myös CPC-CBT -työskentelyä toteuttavien työntekijöiden tiedollisiin ja taidollisiin vaatimuksiin. Työntekijöiden sopivuuden tärkeys korostui, kun lapset ja vanhemmat korostivat yhteistyösuhteen merkitystä työntekijään $(34,35)$. Yhdysvalloissa ja Ruotsissa CPC-CBT -menetelmän käyttö vaatii koulutuksen ja ohjauksellisen tuen ensimmäisen työskentelyprosessin ajalle. Työntekijän ammatillinen perusosaaminen ja kyky työskennellä perheiden kanssa tuomitsemattomassa ilmapiirissä ovat tärkeitä. (16,23,39, 40.) Strukturoitu, tekijävanhemman ja muiden perheenjäsenten kanssa työskentely vaatii ammattiosaamisen lisäksi työntekijän soveltuvuutta $(13,24,29,40)$. Työntekijöiden kyky joustavuuteen perheiden tarpeiden huomioimisessa ja samalla työskentelyrakenteessa pysymisessä on tärkeää (23). Herkkyys ja osaaminen työskentelyn toteuttamiseksi perheenjäsenten mukavuusalueella vaativat taitoja ja työntekijöiden keskinäistä yhteistyötä. $(16,23,27,34,35$.) Lisäksi prosessina etenevässä, teemoitetussa työskentelyssä on kullekin tapaamiskerralle esitetty runsaasti käsiteltäviä aiheita (16). Kun työskentelyyn tulevilla vanhemmilla itsellään on usein väkivaltakokemuksia omasta lapsuudestaan (41) joudutaan ratkaisemaan, miten vanhemman mahdolliset omat kaltoinkohtelukokemukset ja tarve käsitellä niitä toteutetaan. 


\section{POHDINTA}

CPC-CBT on mielenkiintoinen, lupaavia tuloksia saanut väkivaltatyön menetelmä. Toistaiseksi heikkoutena on vähäinen tutkimusten määrä vailla pitkän ajan seurantatuloksia ja koe- ja kontrolliasetelmalla tehtyä tutkimusta. Tutkimusaineistoa tulisi saada kaikilta menetelmää käyttäviltä tahoilta. Vielä ei ole näyttöä siitä, miten CPC-CBT -työskentelyllä on voitu saada aikaan pitkäaikaisia muutoksia väkivallan loppumiseksi. Kirjallisuuskatsauksemme rajautuu englannin- ja ruotsinkieliseen tutkimukseen. Viitteitä muilla kielillä julkaistuista tutkimuksista ei aineistohaun yhteydessä myöskään tullut.

Työskentely on pitkä ja antaa hyvän mahdollisuuden yhteistyösuhteen luomiseen, perheen tilanteeseen perehtymiseen sekä taitojen ja toimintamallien opetteluun ja harjoitteluun. Taitojen ja uusien toimintamallien juurtuminen perheiden käytäntöön vaatii pitkäkestoisen tuen työskentelyn jälkeen (43). Heikkoutena on, että perhe jätetään työskentelyn jälkeen vaille heidän tarvitsemaansa tukea ja valvontaa. Työntekijöidenkin huolena oli opittujen taitojen unohtuminen arjessa (34). On tarpeellista tutkia, millaisesta tuesta perheet hyötyvät työskentelyn jälkeen.

Näyttöön perustuvien työmuotojen onnistunut implementaatio vaatii työmenetelmän käyttäjiksi koulutettavien henkilöiden tietojen ja taitojen lähtötason arviointia ja huomioimista (29). Menetelmäkoulutuksen käyvät sosiaali-, terveysja kasvatusalan ammattilaiset ammattikorkea- ja yliopistotutkinnolla saavat tiedollisen pohjan työskentelyyn. Tutkimustuloksista kävi ilmi, että CPC-CBT vaatii sitä toteuttavilta työntekijöiltä erityisiä ominaisuuksia ja sitoutumista uudenlaisen työskentelytavan reunaehtoihin. Jokainen koulutukseen hakeutuva joutuu itse pohtimaan omaa soveltuvuuttaan menetelmän käyttöön. Tästä koulutusta järjestävien tulee antaa riittävästi tietoa hakijoille. Työskentelyprosessia vetävien tulee myös pystyä toteuttamaan työskentely lähellä perheitä, jotta jokaviikkoiset tapaamiset onnistuvat.

Työskentelyprosessissa vanhemmat vasta opettelevat hyväksyttäviä vuorovaikutustaitoja lasten kanssa toimimiseensa. Lastensuojelun ja CPC-CBT -työntekijöiden keskinäinen yhteistyö lasten turvallisuuden varmistamiseksi on tärkeää. Työntekijät ovat läheisissä yhteistyösuhteissa vaikeissa elämäntilanteissa olevien lasten kanssa ja heidän roolinsa lasten oikeuksien ajajina on hy- vin merkittävä (43). Työskentelyn aikana tietoon tulleeseen lasten kohtaamaan väkivaltaan tulee reagoida heikoissakin signaaleissa $(44,45)$. Väkivalta ei ole sallittua lasten arkea, ja lapsilla on oikeus tarvitsemiinsa palveluihin (45). Työmenetelmän luojat ovat huomioineet, että eri maiden välillä on eroja siinä, mitä käsitetään lapsen kohtaamaksi fyysiseksi väkivallaksi. Jossakin se on täysin kiellettyä, ja jossain sitä määrittelevät jäljet ja vammat. Lähtökohtana työmuodon käytössä tulee olla Lasten oikeudet, joiden mukaan kaikkinainen lapseen kohdistuva fyysinen väkivalta on kiellettyä. (26.) Tämä on tärkeä ohje työntekijöille, jotka tulevat kohtaamaan erilaisia käsityksiä kasvatuksesta.

Tuleeko väkivaltaa lastaan kohtaan käyttäneen vanhemman ja lapsen olla samassa työskentelyssä, on tyhjentävää vastausta vaille jäävä kysymys (14). CPC-CBT :n luojat pitävät lapsen, väkivaltaa käyttävän, väkivaltaa käyttämättömän ja väkivallan käytön riskissä olevan vanhemman yhteistä työskentelyä arvokkaana asiana (26). Turvallisuuden varmistaminen ja seuraaminen edellyttävät katkeamatonta yhteistyötä perheen ympärillä toimivien tahojen kesken. Huolellinen arviointi siitä, kenelle työskentelymalli toimii, auttaa varmistamaan turvallisuutta ja välttämään perheiden keskeytyksiä ja turhautumisia. Arviointi vaatii yhteistä pohdintaa perheen, työskentelyyn perehtyneiden työntekijöiden ja perheitä työskentelyyn ohjaavien tahojen, useimmiten lastensuojelun kesken. On eettisesti tärkeää tarjota perheille juuri heille sopiva työskentely ottaen huomioon turvallisuusnäkökohdat ja vankka sitoutuminen keskeytysten minimoimiseksi. Palvelujen tulee myös tukea perhettä tavoitteiden saavuttamisessa päällekkäisyyttä välttäen. Selkeät työskentelyyn sopivuuden kriteerien huomioiminen ja arviointi työskentelyn sopivuudesta perheelle on ensisijaista. Työnjako ja tiivis yhteistyö eri toimijoiden välillä työskentelyn aikana edesauttavat onnistumisessa.

\section{RAHOITTAJAT:}

Tutkimusta ei ole rahoittanut mikään taho.

\section{KIRJOITTAJIEN KONTRIBUUTIOT:}

Kortelainen vastasi tutkimusaineiston hankinnasta, suunnittelusta, analyysin tekemisestä sekä kirjoituksen kirjoittamisesta. Vornanen ja Anis osallistuivat aineiston tulkintaan, artikkelin kriittiseen tarkistamiseen ja lopullisen version hyväksymiseen. 
In general, the services provided for domestic abuse involve working separately with children and their parents. Parents who use physical discipline towards their children often lack skills in parenting and interaction and are affected by cross-generational issues. Despite this, the domestic abuse services we provide for families lack an evidence-based model for working together with both parents and children.

This paper discusses an evidence-based model developed in the United States of America. The Combined Parent-Child Cognitive Behavioral Therapy -model (CPC-CBT) aims at ending the use of physical discipline and enhancing the interaction between parents and children. The model is also suitable as a preventive measure towards abusive parenting. This model involves working with both parents and children, and it consists of separate sessions as well as joint family sessions.

This article is a descriptive literature review, which provides research information about the CPC-CBT-model. The sample of the review consists of 17 scientific studies or reports that were included in the review in the summer of 2018. The method used content analysis. The results present the experiences of children, parents and employees in participating in CPC-CBT as well as their experiences of the changes achieved by using the method. Furthermore, the article examines the achieved changes in families after participating in CPC-CBT, that were reported in previous literature reviews, as well as information on the skills requirements of employees using the method.

The positive experiences and results of the model are similar both in the United States of America, where the model originates from, and in Sweden. Research results demonstrated that the use of physical discipline has stopped or decreased, children's post-traumatic symptoms have alleviated, the interaction between children and parents has improved and the amount of positive parenting has increased. Most of the studies have had small sample sizes and no long-term follow-up, therefore further research is still needed.

Keywords: Combined Parent-Child Cognitive Behavioral Therapy, maltreatment, discipline, method

Saapunut 05.12.2019

Hyväksytty 14.09.2020

\section{LÄHTEET}

(1) Terveyden ja hyvinvoinnin laitos. Lasten ja nuorten hyvinvointi: Kouluterveyskysely 2019 . Tilastoraportti 33/2019. Luettu 2.6.2020. http://urn.fi/URN:NBN:fi-fe2019091528281

(2) Fadjukoff M, Harrikari T. Epäily lapseen kohdistuneesta rikoksesta - esilletulo ja ilmoittaminen poliisille. Yhteiskuntapolitiikka 2020;85(1):42-54.

(3) Hynynen R, Paavilainen E, Kylmä J, ym. Nuorten näkemyksiä kuritusväkivallan syistä ja seurauksista. Hoitotiede 2015;27(2):93-103.

(4) Hyvärinen S. Piiskasta jäähypenkkiin. Suomalaisten kasvatusasenteet ja kuritusväkivallan käyttö 2017. Lastensuojeluliiton keskusliiton verkkojulkaisu 2/2017. Luettu 12.9.2019. https://www.lskl.fi/materiaali/ lastensuojelun-keskusliitto/Piiskastajaahypenkkiin-1.pdf

(5) Ellonen N, Peltonen K, Pösö T, ym. A Multifaceted Risk Analysis of Fathers`SelfReported Physical Violence Toward Their

Children. Aggr Behav 2017;43(4):317-328. doi: 10.1002/ab.21691

(6) Peltonen K, Ellonen N, Pösö T, ym. Mothers self-reported violence toward their children: A multifaceted risk analysis. Child Abuse \& Negl 2014:38:1923-1933. doi: 10.1016/j.chiabu.2014.10.016

(7) Terveyden ja hyvinvoinnin laitos. Väkivaltakäsitteiden sanasto. Työpaperi 1/2020. Luettu 2.6.2020. http://www.julkari.fi/ bitstream/handle/10024/139150/URN_ ISBN_978-952-343-211-6.pdf

(8) Laki lapsen huollosta ja tapaamisoikeudesta 8.4.1983/361. https://www.finlex.fi/fi/laki/ alkup/1983/19830361 17.10.2018

(9) Asetus lapsen oikeuksia koskevan yleissopimuksen voimaansaattamisesta sekä yleissopimuksen eräiden määräysten hyväksymisestä annetun lain voimaantulosta. 21.8.1991/60. https://www.finlex.fi/fi/sopimukset/ sopsteksti/1991/19910060/19910060_1 
(10) Valtioneuvoston asetus naisiin kohdistuvan väkivallan ja perheväkivallan ehkäisemisestä ja torjumisesta tehdyn Euroopan neuvoston yleissopimuksen voimaansaattamisesta sekä yleissopimuksen lainsäädännön alaan kuuluvien määräysten voimaansaattamisesta annetun lain voimaantulosta. 1.8.2015/53. https://finlex.fi/fi/sopimukset/ sopsteksti/2015/20150053/20150053_1

(11) Valtioneuvosto. Väkivallaton lapsuus: toimenpidesuunnitelma lapsiin kohdistuvan väkivallan ehkäisystä 2020-2025. Luettu 2.6.2020. http://urn.fi/ URN:ISBN:978-952-00-4123-6

(12) Ellonen N, Pösö T, Peltonen K. Äidit ja lapsiin kohdistuva väkivalta. Kyselytutkimuksen pohdintaa. Yhteiskuntapolitiikka 2015;80(1): 72-80.

(13) Schneider SJ, Grilli SF, Schneider JR. Evidence-Based Treatments for Traumatized Children and Adolescents. Curr Psychiatry Rep 2013;15(332):1-9. doi: $10.1007 / \mathrm{s} 11920-012-0332-5$

(14) Dorsey S, McLaughlin KA, Kerns SEU, ym. Evidence Base Update for Psychosocial Treatments for Children and Adolescents Exposed to Traumatic Events. J Clin Child Adolesc Psychol 2017;46(3):303-330. doi: 10.1080/15374416.2016.1220309

(15) Leenarts LEW, Diehle J, Doreleijers TAH, ym. Evidence-based treatments for children with trauma-related psychopathology as a result of childhood maltreatment: a systematic review. Eur Child Adolesc Psychiatry 2013;22: 269-283. doi: 10.1007/s00787-012-0367-5

(16) Runyon MK, Deblinger E. Combined ParentChild Cognitive Behavioral Therapy. An Approach to Empower Families At-Risk for Child Physical Abuse. Oxford: University Press; 2014.

(17) Svedin CG, Nilsson D, Kjellgren C, ym. Slutrapport: KIBB projektet Kognitiv Integrerad Behandling vid Barnmisshandel 2013-2015. Tukholma: Stiftelsen Allmänna Barnhuset; 2015.

(18) Thulin J, Kjellgren C. Implementing and evaluating the CPC-CBT intervention in a Swedish context. Tukholma: Stiftelsen Allmänna Barnhuset; 2018.

(19) Temcheff CE, Letarte M-J, Boutin S, ym. Common components of evidencebased parenting programs for preventing maltreatment of school-age children. Child Abuse Negl 2018;(80):226-237. doi: 10.1016/j.chiabu.2018.02.004

(20) Vlahovicova K, Melendez-Torres GJ, Leijten $\mathrm{P}, \mathrm{ym}$. Parenting Programs for the Prevention of Child Physical Abuse Recurrence: A Systematic Review and Meta-Analysis. Clin Child Fam Psychol Rev 2017;20:351-365. doi: 10.1007/s10567-017-0232-7

(21) Goldman Fraser J, Lloyd S, Murphy R, ym. A Comparative Effectiveness Review of Parenting and Trauma-Focused Interventions for Children Exposed to Maltreatment.
J Dev Behav Pediatr 2013;34(5):353-368. doi: 10.1097/DBP.0b013e31828a7dfc

(22) California Evidence-Based Clearinghouse for Child Welfare. Information and Resources for Child Welfare Professionals. Combined ParentChild Cognitive-Behavioral Therapy (CPC-CBT). Luettu 12.9.2019. https://www.cebc4cw.org/ program/combined-parent-child-cognitivebehavioral-therapy-cpc-cbt/

(23) Runyon MK, Deblinger E, Schroeder CM. Pilot Evaluation of Outcomes of Combined Parent-Child Cognitive-Behavioral Group Therapy for Families at Risk for Child Physical Abuse. Cogn Behav Pract 2009;16:101-118. doi: 10.1016/j.cbpra.2008.09.006

(24) Runyon MK, Deblinger E, Steer RA. Group Cognitive Behavioral Treatment for Parents and Children At-Risk for Physical Abuse: An Initial Study. Child \& Family Behavior Therapy 2010;32(3):196-218. doi: 10.1080/07317107.2010.500515

(25) Runyon MK, Mclean C. Empowering Families. Combined Parent-Child Cognitive Behavioral Therapy for Families at Risk for Child Physical Abuse. Teoksessa Reece RM, Hanson RF, Sargent, J. (toim.) Treatment of Child Abuse. Common Ground for Mental Health, Medical, and Legal. 2. uud. p. Baltimore: Johns Hopkins University Press; 2014, 67-75.

(26) Runyon MK, Cruthirds S, Deblinger E. EvidenceBased Approaches to Empower Children and Families at Risk for Child Physical Abuse to Overcome Abuse and Violence. Teoksessa: Dixon L, Perkins DF, Hamilton-Giarcritsis C, Leam AC (toim.). The Wiley Handbook of What Works in Child Maltreatment: An EvidenceBased Approach to Assessment and Intervention in Child Protection. USA: John Wiley \& Sons Ltd.2017, 297-312.

(27) Runyon MK, Deblinger E, Ryan EE, ym. An Overview of Child Physical Abuse. Developing an Integrated Parent-Child Cognitive-Behavioral Treatment Approach. Trauma Violence Abuse 2004:5(1):65-85. doi: $10.1177 / 1524838003259323$

(28) Santini PM, Williams LCA. Parenting Programs to Prevent Corporal Punishment: A Systematic Review. Paidèia. 2016; 26(63):121-129. doi: 10.1590/1982-43272663201614

(29) Fixen DL, Blase KA, Naoom S-F ym. Core Implementation Components. Reseach on Social Work Practice 2009;19(5):531-540. doi:10.1177/1049731509335549

(30) Johansson K, Axelin A, Stolt M, Ääri RL. (toim.) Systemaattinen kirjallisuuskatsaus ja sen tekeminen. Turku: Turun yliopisto; 2007.

(31) Aveyard H. Doing a Literature Review in Health and Social Care: A Practical Guide. 2.uud.p. London: McGraw-Hill Education; 2010.

(32) Salminen A. Mikä kirjallisuuskatsaus? Johdatus kirjallisuuskatsauksen tyyppeihin ja hallintotieteellisiin sovelluksiin. Luettu 12.9.2019. http://urn.fi/ URN:ISBN:978-952-476-349-3 
(33) Eskola J, Suoranta J. Johdatus laadulliseen tutkimukseen. 10. uud. p. Tampere: Vastapaino; 2014.

(34) Thulin J. Samtal med barn och föräldrar samt KIBB-behandlare, socialsekreterare och åklagare. Raportissa: Svedin CG, Nilsson D, Kjellgren C, ym. Slutrapport: KIBB projektet Kognitiv Integrerad Behandling vid Barnmisshandel 2013-2015. Tukholma: Stiftelsen Allmänna Barnhuset; 2015, 29-37.

(35) Thulin J, Kjellgren C, Nilsson D. Children`s experiences with an intervention aimed to prevent further physical abuse. Child \& Family Social Work 2018;1-8. doi: $10.1111 /$ cfs. 12476

(36) Kjellgren C, Svedin CG, Nilsson D. Child Physical Abuse - Experiences of Combined Treatment for Children and their Parents: A pilot study. Child Care in Practice 2013;19(3):275-290. doi: 10.1007/s11920-012-0332-5

(37) Thulin J, Kjellgren C. Treatment in Barnahus: Implementing Combined Treatment for Children and Parents in Physial Abuse Cases. Luettu 23.10.2018. Kirjassa: Johansson S, Stefansen K, Bakketeig E, Kaldal A. (toim.). Collaborating Against Child Abuse 2017;75-94. doi: 10.1007/978-3-319-58388-4_4

(38) Kjellgren C, Nilsson D, Thulin J. Implementering av en strukturerad behandlingsmodell vid barnmisshandel - ett tioårsperspektiv. Socialmedicinsk tidskrift 2017;4:457-466, 476.

(39) Cares Institute. Child Abuse Research Education \& Service. How to Implement Combined ParentChild Cognitive Behavioral Therapy (CPC-CBT). Luettu 20.10.2018. http://melissarunyon.com/ wp-content/uploads/2017/03/ImplementationGuide-CPC-CBT-082410.pdf

(40) Söderlind Göthner Y. KIBB utbildningen. Raportissa: Svedin CG, Nilsson D, Kjellgren C, ym. Slutrapport: KIBB projektet Kognitiv Integrerad Behandling vid Barnmisshandel 20132015. Tukholma: Stiftelsen Allmänna Barnhuset; 2015, 39-41.
(41) Santa-Sosa EJ, Runyon MK. Addressing Ethnocultural Factors in Treatment for Child Physical Abuse. J Child Fam Stud 2014;24:1660-1671. doi: 10.1007/s10826-014-9969-5

(42) Thulin J, Kjellgren C, Nilsson D. Forskningsstudien. Raportissa: Svedin CG, Nilsson D, Kjellgren C, ym. Slutrapport: KIBB projektet Kognitiv Integrerad Behandling vid Barnmisshandel 2013-2015. Tukholma: Stiftelsen Allmänna Barnhuset 2015, 21-28.

(43) Van der Put CE, Assink M, Gubbels J, ym. Identifying Effective Components of Child Maltreatment Interventions: A Meta-analysis. Clin Child Fam Psychol Rev 2018;21:171-202. doi: 10.1007/s10567-017-0250-5

(44) Eydal GB, Satka M. Social work and Nordic welfare policies for children - present challenges in the light of the past. European Journal of Social Work 2006;9(3):305-322. doi: 10.1080/13691450600828358

(45) Ellonen N, Pösö T. Hesitation as a System Response to Children Exposed toViolence. International Journal of Children`s Rights 2014;22:730-747. doi: 10.1163/15718182-02204001

\section{Merja Kortelainen \\ YTM, erikoissosiaalityöntekijä \\ Viola - väkivallasta vapaaksi ry \\ Ensi- ja turvakotien liiton Ylisukupolvisen \\ kaltoinkobtelun katkaiseminen -hanke}

\section{RiITTA VoRnANEN \\ YTT, sosiaalityön professori \\ Itä-Suomen yliopisto \\ Yhteiskuntatieteiden laitos}

Merja Anis

VTT, sosiaalityön professori

Turun yliopisto

Sosiaalitieteiden laitos 